\title{
Calcium carbonate production response to future ocean warming and acidification
}

\author{
A. J. Pinsonneault ${ }^{1,2}$, H. D. Matthews ${ }^{1}$, E. D. Galbraith ${ }^{3}$, and A. Schmittner ${ }^{4}$ \\ ${ }^{1}$ Department of Geography, Planning and Environment, Concordia University, 1455 de Maisonneuve Blvd W., H3G 1M8, \\ Montreal, QC, Canada \\ ${ }^{2}$ Department of Geography, McGill University, 805 Sherbrooke Street West, H3A 0B9, Montreal, QC, Canada \\ ${ }^{3}$ Department of Earth and Planetary Sciences, McGill University, 3450 University, H3A 2A7, Montreal, QC, Canada \\ ${ }^{4}$ College of Oceanic and Atmospheric Sciences, Oregon State University, 104 CEOAS Administration Building, \\ Corvallis, OR 97331-5503, USA
}

Correspondence to: A. J. Pinsonneault (andrew.pinsonneault@mail.mcgill.ca)

Received: 16 November 2011 - Published in Biogeosciences Discuss.: 13 December 2011

Revised: 28 April 2012 - Accepted: 1 June 2012 - Published: 29 June 2012

\begin{abstract}
Anthropogenic carbon dioxide $\left(\mathrm{CO}_{2}\right)$ emissions are acidifying the ocean, affecting calcification rates in pelagic organisms, and thereby modifying the oceanic carbon and alkalinity cycles. However, the responses of pelagic calcifying organisms to acidification vary widely between species, contributing uncertainty to predictions of atmospheric $\mathrm{CO}_{2}$ and the resulting climate change. At the same time, ocean warming caused by rising $\mathrm{CO}_{2}$ is expected to drive increased growth rates of all pelagic organisms, including calcifiers. It thus remains unclear whether anthropogenic $\mathrm{CO}_{2}$ emissions will ultimately increase or decrease pelagic calcification rates. Here, we assess the importance of this uncertainty by introducing a dependence of calcium carbonate $\left(\mathrm{CaCO}_{3}\right)$ production on calcite saturation state $\left(\Omega_{\mathrm{CaCO}_{3}}\right)$ in an intermediate complexity coupled carbonclimate model. In a series of model simulations, we examine the impact of several variants of this dependence on global ocean carbon cycling between 1800 and 3500 under two different $\mathrm{CO}_{2}$ emissions scenarios. Introducing a calcificationsaturation state dependence has a significant effect on the vertical and surface horizontal alkalinity gradients, as well as on the removal of alkalinity from the ocean through $\mathrm{CaCO}_{3}$ burial. These changes result in an additional oceanic uptake of carbon when calcification depends on $\Omega_{\mathrm{CaCO}_{3}}$ (of up to $270 \mathrm{Pg} \mathrm{C}$ ), compared to the case where calcification does not depend on acidification. In turn, this response causes a reduction of global surface air temperature of up to $0.4{ }^{\circ} \mathrm{C}$ in year 3500. Different versions of the model produced varying
\end{abstract}

results, and narrowing this range of uncertainty will require better understanding of both temperature and acidification effects on pelagic calcifiers. Nevertheless, our results suggest that alkalinity observations can be used to constrain model results, and may not be consistent with the model versions that simulated stronger responses of $\mathrm{CaCO}_{3}$ production to changing saturation state.

\section{Introduction}

Ocean uptake of atmospheric carbon dioxide $\left(\mathrm{CO}_{2}\right)$ is having a profound effect on biochemical cycles and ocean ecosystems. Increased $\mathrm{CO}_{2}$ dissolution in the surface ocean leads to a decrease in seawater $\mathrm{pH}$ (Secretariat of the Convention on Biological Diversity, 2009, hereafter SCBD, 2009). This, in turn, leads to a decrease in carbonate ion concentration $\left(\left[\mathrm{CO}_{3}^{2-}\right]\right)$, a shoaling of both the calcium carbonate $\left(\mathrm{CaCO}_{3}\right)$ saturation horizon and lysocline, and an alteration of $\mathrm{CaCO}_{3}$ stored in deep-sea sediments. This process, known as ocean acidification, has the potential to severely impact the biological carbon pumps, which influence the vertical alkalinity (ALK) and dissolved inorganic carbon (DIC) gradients in the ocean. Consequently, ocean acidification could affect the strength of the ocean as a carbon sink and, ultimately, the rate and magnitude of global climate change.

Biogenic calcification describes the formation of $\mathrm{CaCO}_{3}$ by certain species of marine biota that use $\mathrm{CaCO}_{3}$ to create 
their shells and skeletons (Doney et al., 2009; SCBD, 2009). In general, the rate of biogenic calcification depends on the saturation state of $\mathrm{CaCO}_{3}$ in the surface ocean defined as

$\Omega_{\mathrm{CaCO}_{3}}=\left[\mathrm{Ca}^{2+}\right]\left[\mathrm{CO}_{3}^{2-}\right] / K_{\mathrm{sp}}^{*}$

where $\left[\mathrm{Ca}^{2+}\right]$ is the calcium ion concentration and $K_{\mathrm{sp}}^{*}$ is the stoichiometric solubility product, which increases with decreasing temperature and increasing pressure. As $\left[\mathrm{Ca}^{2+}\right]$ is assumed to be constant throughout the global oceans (Millero, 1979), seawater $\Omega_{\mathrm{CaCO}_{3}}$ is governed by $\left[\mathrm{CO}_{3}^{2-}\right]$, which will decrease as a result of ocean acidification over the coming centuries. Prior modelling studies have suggested that over the next $100-400 \mathrm{yr}$, a greater extent of both the surface oceans and waters at depth, particularly at high latitudes, will become undersaturated $(\Omega<1)$ with respect to calcite and/or aragonite, two different polymorphs of $\mathrm{CaCO}_{3}$ (Andersson et al., 2006; Caldeira and Wickett, 2005; Cao and Caldeira, 2008; Orr et al., 2005).

\subsection{Calcifier response}

Calcifying marine life, such as coccolithophores and Foraminifera, may be vulnerable to those predicted changes in $\Omega_{\mathrm{CaCO}_{3}}$ (Doney et al., 2009; SCBD, 2009) as well as to changes in seawater pH (Hinga, 2002). However, laboratory and mesocosm studies have suggested large interspecies variability in the calcifying response to acidification (Delille et al., 2005; Engel et al., 2005; Iglesias-Rodriguez et al., 2008; Langer et al., 2006; Riebesell et al., 2000; Sciandra et al., 2003; Zondervan et al., 2001). Global-scale models of the carbon cycle used to predict the potential impacts of anthropogenic $\mathrm{CO}_{2}$ emissions base their parameterizations on the results of such studies (e.g. Gangstø et al., 2011; Gehlen et al., 2007; Heinze, 2004; Hofmann and Schellnhuber, 2009; Ridgwell et al., 2007a, b). Consequently, this variability in calcifier response to ocean acidification introduces a large uncertainty to predictions of how the $\mathrm{CO}_{2}$-calcification feedback will operate in the future (Doney, 2009; Doney et al., 2009; Ridgwell et al., 2009).

In addition to the uncertainty in species-specific responses to acidification, significant changes in ocean ecosystems are expected to arise from ocean warming (Doney, 2010). Among these is the effect of increasing temperature on ocean primary production. There is, however, uncertainty in just how ocean primary production will respond to climate warming, leading to different model parameterizations of this temperature effect. For example, using an ensemble of models, Steinacher et al. (2010) predicted a decrease in biological production due to a reduced nutrient supply in a warmer and more stratified ocean in the 21 st century. Over the same time frame, however, Schmittner et al. (2008) predicted an increase in surface ocean primary production with temperature due to a temperature-dependent parameterization of phytoplankton growth rates in their model. In this case, because organic matter is recycled in the upper ocean much more efficiently than $\mathrm{CaCO}_{3}$, enhanced biological production would be expected to result in an increase of the export of inorganic $\mathrm{CaCO}_{3}$ particles relative to that of organic carbon. Moreover, the fact that organic export is more readily limited by nutrient supply could allow $\mathrm{CaCO}_{3}$ export to significantly outstrip organic matter export in a warmer ocean, where recycled nutrients drive production. Thus, more rapid production of $\mathrm{CaCO}_{3}$ due to higher temperatures (Schmittner et al., 2008) could potentially counteract the effect of acidification on calcification.

\subsection{Ocean sediments and rain ratio}

A change in the ratio of $\mathrm{CaCO}_{3}$ (PIC) to organic matter (POC) export from the surface to the deep ocean could impact $\mathrm{CaCO}_{3}$ accumulation and dissolution in ocean sediments. On the one hand, whether due to reduced calcification or enhanced primary production, a greater export of POC relative to PIC would lead to changes in the respective accumulation rates in ocean sediments (Riebesell et al., 2000; Zondervan et al., 2001). An increase in organic carbon accumulation relative to inorganic carbon in the sediments would result in the acidification of the sediment pore waters via organic matter decomposition (Emerson and Bender, 1981; Gehlen et al., 2008). This, in turn, would lead to greater metabolic dissolution of sedimentary $\mathrm{CaCO}_{3}$ resulting in an increase in ocean alkalinity (Archer and MaierReimer, 1994). This enhanced sediment $\mathrm{CaCO}_{3}$ dissolution, exacerbated by the invasion of anthropogenic $\mathrm{CO}_{2}$ into the deep ocean via large-scale ocean circulation, impacts deepocean chemistry on century timescales (Gehlen et al., 2008) and acts as a negative feedback on atmospheric $\mathrm{CO}_{2}$ on timescales of $10^{3}-10^{4} \mathrm{yr}$ (Archer, 2005; Archer and MaierReimer, 1994; Archer et al., 1997, 1998; Broecker and Peng, 1987; Lenton and Britton, 2006; Ridgwell and Hargreaves, 2007; Ridgwell et al., 2007b; Sundquist, 1985, 1990). On the other hand, if changes in the rain ratio are restricted by the process of ballasting (e.g. Armstrong et al., 2002; Barker et al., 2003; Klaas and Archer, 2002; Ridgwell, 2003), a reduction in $\mathrm{CaCO}_{3}$ production would result in a shallower POC remineralization horizon. This would lead to greater surface ocean $p \mathrm{CO}_{2}$ and act as a positive feedback on atmospheric $\mathrm{CO}_{2}$ (Barker et al., 2003). The importance of mineral ballasting in the export of POC to the deeper ocean, however, remains highly uncertain (Francois et al., 2002; Passow and De la Rocha, 2006).

\subsection{Modelling studies}

Whether due to the effects of acidification or warming, changes in biogenic calcification have important implications for oceanic carbon storage. The oceans have sequestered approximately $30-40 \%$ of anthropogenic $\mathrm{CO}_{2}$ in the last $200 \mathrm{yr}$ (Feely et al., 2004; Raven and Falkowski, 1999; Sabine et al., 
2004; Zeebe et al., 2008). Changes in $\mathrm{CaCO}_{3}$ production, a process that consumes 2 moles of alkalinity for every mole of DIC, can alter the oceanic $\mathrm{CO}_{2}$ uptake capacity via a greater change in sea surface alkalinity relative to DIC (Denman et al., 2007; Sabine et al., 2004). Consequently, a reduction in $\mathrm{CaCO}_{3}$ production would increase the rate of ocean $\mathrm{CO}_{2}$ uptake resulting in a negative feedback on increasing anthropogenic $\mathrm{CO}_{2}$ levels.

Several recent modelling studies have been conducted to examine changes in $\mathrm{CaCO}_{3}$ production rates due to acidification and their effect on the fate of anthropogenic $\mathrm{CO}_{2}$ (Andersson et al., 2006; Gangst $\varnothing$ et al., 2008; Gehlen et al., 2007; Heinze, 2004). Despite significant research attention, however, estimates of the current rate of global $\mathrm{CaCO}_{3}$ production vary widely: from 0.4 to $1.8 \mathrm{Pg} \mathrm{Cyr}^{-1}$ (Doney et al., 2009). Modelled estimates of the calcification response to ocean acidification are even more uncertain, because model parameterizations of the $\mathrm{CO}_{2}$-calcification feedback are based on the disparate results of laboratory and mesocosm calcification studies (Ridgwell et al., 2009). For example, Heinze (2004) based their model parameterization of the $\mathrm{CO}_{2}$-calcification feedback on data from the laboratory calcification study by Zondervan et al. (2001) and predicted $\mathrm{CaCO}_{3}$ production would decrease by $38 \%$ when atmospheric $p \mathrm{CO}_{2}$ reached $1000 \mathrm{ppmv}$ after $420 \mathrm{yr}$. In contrast, Gehlen et al. (2007) based their parameterization of this feedback on more recent laboratory and mesocosm calcification studies (Delille et al., 2005; Zondervan et al., 2002) and predicted that global $\mathrm{CaCO}_{3}$ production would decrease by $27 \%$ over $140 \mathrm{yr}$ following an increase of atmospheric $p \mathrm{CO}_{2}$ from 286-1144 ppmv.

With little agreement amongst modelling studies regarding the predicted strength of the $\mathrm{CO}_{2}$-calcification feedback or the ultimate fate of anthropogenic $\mathrm{CO}_{2}$, some studies have attempted to address this disparity by assessing different parameterizations encapsulating a range of calcification responses to ocean acidification (Gangst $\varnothing$ et al., 2011; Ilyina et al., 2009; Ridgwell et al., 2007b, 2009). These studies have found that the stronger the calcification- $\Omega_{\mathrm{CaCO}}$ relationship in the parameterization of the $\mathrm{CO}_{2}$-calcification feedback, the greater the increase in sea surface alkalinity and oceanic carbon sequestration (Gangst $\varnothing$ et al., 2011; Ilyina et al., 2009; Ridgwell et al., 2007b). Although studies agree that the $\mathrm{CO}_{2}$-calcification feedback is relatively small (Gangst $\varnothing$ et al., 2011; Ridgwell et al., 2007b, 2009; Zondervan et al., 2001), it still contributes uncertainty to climate model predictions. Consequently, it is critical that this feedback be properly represented in modelling studies, especially on centennial and longer timescales. It is also important to note that most modelling studies specifically addressing the uncertainty in the $\mathrm{CO}_{2}$-calcification feedback parameterization are either conducted on centennial timescales or omit deepsea carbonate sediment dissolution. Therefore, longer-term parameterization sensitivity studies accounting for carbonate sediment dynamics are required. Moreover, most studies of future $\mathrm{CaCO}_{3}$ production projections have focused only on ocean acidification effects and neglected the temperature effect, although both may be similarly important for long-term ocean carbon cycle changes.

The purpose of this study is to expand on the work of Gangst $\varnothing$ et al. (2011), Ilyina et al. (2009), and Ridgwell et al. (2007b) by (1) incorporating a parameterization of the $\mathrm{CO}_{2}$-calcification feedback into an intermediate complexity climate model; (2) exploring a range of calcification responses, reflecting experimental uncertainty in the biogenic calcification response to increasing ocean carbon uptake; (3) comparing acidification and temperature effects on future $\mathrm{CaCO}_{3}$ production; (4) evaluating different model solutions with modern observations; and (5) assessing the resulting impact on the magnitude and direction of future ocean carbonclimate feedbacks on millennial timescales in response to two different $\mathrm{CO}_{2}$ emission scenarios.

\section{Materials and methods}

\subsection{Model description}

In this study, we used the University of Victoria Earth System Climate Model (UVic ESCM) version 2.9, an intermediate complexity global climate model with a spherical grid resolution of $1.8^{\circ}$ latitude by $3.6^{\circ}$ longitude. The climate component of the model consists of a simplified energy-moisture balance atmospheric model with dynamical feedbacks, coupled to a primitive equation three-dimensional ocean general circulation model (Modular Ocean Model 2 or MOM2), and a thermodynamic/dynamic sea ice model (Weaver et al., 2001). The carbon cycle component of the model is represented by a dynamic vegetation model (Top-down Representation of Interactive Foliage and Flora Including Dynamics or TRIFFID) (Cox, 2001; Meissner et al., 2003), a land surface model (a simplified version of the Met Office Surface Exchange Scheme or MOSES) (Meissner et al., 2003), an ocean ecosystem/biogeochemical model and an inorganic ocean carbon model (Schmittner et al., 2008), and an oxiconly model of ocean sediment respiration (Archer, 1996; Eby et al., 2009).

The MOM2 ocean component includes numerous physical parameterizations such as diffusive mixing along and between layers of different water density, eddy-induced tracer transport based on Gent and McWilliams (1990), and the computation of tidally induced diapycnal mixing over rough seafloor topography (Simmons et al., 2004). Radiocarbon ${ }^{14} \mathrm{C}$ and chlorofluorocarbons (CFCs) are used to track the ocean's ventilation to the atmosphere on decadal to millennial scales (Schmittner et al., 2008). The inorganic carbon cycle model is an Ocean Carbon-Cycle Model Intercomparison (OCMIP-2) type model, while the ocean ecosystem/biogeochemical model is a nutrient-phytoplanktonzooplankton-detritus (NPZD) model based on Schmittner et 
al. (2005a) with a fast microbial induced nutrient recycling parameterization based on Schartau and Oschlies (2003). The NPZD model further includes two kinds of phytoplankton (nitrogen fixers and other phytoplankton, $\mathrm{P}_{\mathrm{o}}$ ), nutrients such as phosphate $\left(\mathrm{PO}_{4}\right)$ and nitrate $\left(\mathrm{NO}_{3}\right)$, and tracers such as DIC, alkalinity, and oxygen $\left(\mathrm{O}_{2}\right)$.

The production of $\mathrm{CaCO}_{3}$ in the model is calculated as

$$
\begin{aligned}
\operatorname{Pr}\left(\mathrm{CaCO}_{3}\right) & =\left((1-\beta) \mathrm{G}\left(\mathrm{P}_{\mathrm{o}}\right) \mathrm{Z}+\mu_{\mathrm{P}_{2}} \mathrm{P}_{\mathrm{o}}^{2}\right. \\
& \left.+\mu_{\mathrm{z}} \mathrm{Z}^{2}\right)\left(\mathrm{PIC}^{*}: \mathrm{POC}^{*}\right) R_{\mathrm{C}: \mathrm{P}}
\end{aligned}
$$

where $(1-\beta) G\left(P_{o}\right) Z$ represents the zooplankton grazing of the $\mathrm{P}_{\mathrm{o}}$ phytoplankton type, $\mu_{\mathrm{P}_{2}} \mathrm{P}_{\mathrm{o}}^{2}$ represents the mortality of $\mathrm{P}_{\mathrm{o}}$ phytoplankton, $\mu_{\mathrm{z}} \mathrm{Z}^{2}$ represents zooplankton mortality, ( $\mathrm{PIC}^{*}: \mathrm{POC}^{*}$ ) is the production ratio of $\mathrm{CaCO}_{3}$ to particulate organic carbon, and $R_{\mathrm{C}: \mathrm{P}}$ is the molar elemental ratio of carbon to phosphorus (Schmittner et al., 2008). The zooplankton grazing and mortality variables are included in this calculation because Foraminifera, which are calcifying zooplankton, are a significant source of $\mathrm{CaCO}_{3}$ production (Doney et al., 2009; Raven and Falkowski, 1999). Dissolution of $\mathrm{CaCO}_{3}$ in the water column is calculated by assuming instantaneous sinking of the vertically integrated production as per the following equation:

$$
\operatorname{Di}\left(\mathrm{CaCO}_{3}\right)=\int \operatorname{Pr}\left(\mathrm{CaCO}_{3}\right) \mathrm{d} z \cdot \frac{\mathrm{d}}{\mathrm{d} z}\left(e^{-z / \mathrm{DCaCO}_{3}}\right)
$$

where $z$ is the depth relative to the surface and $\mathrm{DCaCO}_{3}$ is the $e$-folding depth (set at $6500 \mathrm{~m}$ ). As the vertically integrated $\mathrm{CaCO}_{3}$ (PIC) production in the model is parameterized as a fixed ratio of the production of nondiazotrophic detritus (POC), the strength of the $\mathrm{CaCO}_{3}$-pump is strongly influenced by the PIC*:POC* parameter (Schmittner et al., 2008).

Phytoplankton growth rates have been shown to increase exponentially with temperature (Eppley, 1972; Bissinger et al., 2008). Bacterial and zooplankton respiration rates also depend strongly on temperature (Kirchman and Rich, 1997; Pomeroy and Wiebe, 2001; Sarmento et al., 2010; White et al., 1991). In the model, maximum rates of phytoplankton growth, fast recycling (a bacterially mediated flux from phytoplanton biomass to the inorganic nutrient pool), excretion rates of zooplankton (a flux from zooplankton biomass to the inorganic nutrient pool), and remineralization of detritus (sinking particulate organic matter) are all assumed to depend exponentially on temperature, such that they increase by a factor of $Q_{10}=1.9$ for a $10^{\circ} \mathrm{C}$ temperature increase (Schmittner et al., 2008). As $\mathrm{CaCO}_{3}$ production in the model is parameterized as a fixed ratio of nondiazotrophic detrital production ( $\mathrm{PIC}^{*}: \mathrm{POC}^{*}$ in $\mathrm{Eq} .2$ ), $\mathrm{CaCO}_{3}$ production rates tend to increase along with detrital production rates in response to increasing sea surface temperatures (Schmittner et al., 2008).

The marine sediment component consists of 13 layers ranging from a few millimeters near the sediment surface to a few centimeters at the bottom of the domain at a depth of $10 \mathrm{~cm}$. The penetration depth of POC into the sediment bioturbated layer is determined by the balance between the respiration rate constant and the sediment-mixing rate. Sediment $\mathrm{CaCO}_{3}$ dissolution is simulated using a model of $\mathrm{CaCO}_{3}$ dissolution kinetics coupled to the $\mathrm{pH}$ reaction and diffusion of carbonate buffer species $\left(\mathrm{CO}_{2}, \mathrm{HCO}_{3}^{-}, \mathrm{CO}_{3}^{2-}\right)$ in the sediment pore water (Archer, 1991, 1996; Emerson and Bender, 1981). The concentration and burial rates of sedimentary $\mathrm{CaCO}_{3}$ are predicted using the PIC:POC rain ratio, dilutant burial rates (primarily clay and opal), and the reaction rate laws for both organic carbon and $\mathrm{CaCO}_{3}$ (Archer, 1996). The sediment component accounts for the oxic metabolic dissolution of sedimentary $\mathrm{CaCO}_{3}$, a detailed description of which can be found in Archer (1991). The effects of suboxic and anoxic metabolism, however, are not accounted for in the model (Eby et al., 2009).

It should be noted that the UVic ESCM does not differentiate between the different polymorphs of $\mathrm{CaCO}_{3}$ (aragonite and calcite). In this study we focus on the dependence of calcification on calcite saturation state only $\left(\Omega_{\mathrm{CaCO}_{3}}\right)$, which is a reasonable approximation, given that $65-90 \%$ of pelagic calcification is in the form of calcite (Fabry, 1990; Gangst $\varnothing$ et al., 2008). Furthermore, mineral ballasting, which increases the efficiency of POC export to the deep sea, is not represented in the UVic ESCM; the model therefore assumes an independence of organic and inorganic material fluxes to the deep ocean. Finally, for the purposes of this study, we have focused on the production dependence on $\Omega_{\mathrm{CaCO}_{3}}$, and have not also introduced a dependence of $\mathrm{CaCO}_{3}$ dissolution in the water column on $\Omega_{\mathrm{CaCO}_{3}}$.

\subsection{Model experimental methodology}

We present a series of transient model simulations from the year 1800 to 3500 , so as to reasonably cover one full cycle of the oceanic meridional overturning circulation. In order to achieve a stable preindustrial climate, all model configurations were individually integrated for 10000 model years using fixed preindustrial boundary conditions. During this spin-up phase, ocean alkalinity was conserved, with alkalinity input from terrestrial weathering matched by the burial of alkalinity in ocean sediments. Subsequently, during the transient simulations described below, the weathering flux was held constant at the preindustrial rate.

We performed two suites of transient runs, each with six simulations (corresponding to the six versions of the calcification responses described below). The first suite (suite $\mathrm{S}$ ) was forced by the Intergovernmental Panel on Climate Change's "business-as-usual" SRES A2 $\mathrm{CO}_{2}$ emissions scenario, reaching cumulative $\mathrm{CO}_{2}$ emissions of $2166 \mathrm{Pg} \mathrm{C}$ by the year 2100. After 2100, emissions were set to zero for the duration of the simulations. The second suite (suite M) was forced by a "mitigation" emissions scenario, in which emissions peaked in the year 2020 and decreased to zero 
Table 1. Summary of model run calibrations.

\begin{tabular}{llllll}
\hline Scenarios & $\begin{array}{l}\text { Cumulative } \mathrm{CO}_{2} \\
\text { Emissions by } \\
2100(\mathrm{Pg} \text { C) }\end{array}$ & $\mathrm{K}_{\max }$ & $(\mathrm{PIC}: \mathrm{POC})_{\max }$ & $\begin{array}{l}\text { PIC:POC at } \\
\text { Preindustrial } \\
\text { Surface } \Omega_{\text {calcite }}\end{array}$ & $\begin{array}{l}\text { Preindustrial } \\
\text { Surface } \Omega_{\text {calcite }}\end{array}$ \\
\hline S0 & & - & - & & \\
S1 & 0.07 & 0.0183 & & \\
S2 & 2166 Pg C (all S) & 0.5 & 0.0204 & & \\
S3 & & 3.5 & 0.0251 & & \\
S4 & & 20 & 0.0322 & & \\
S5 & & - & - & & \\
\hline M0 & & 0.07 & 0.0183 & \\
M1 & & 0.5 & 0.0204 & & \\
M2 & 1000 Pg C (all M) & 1.5 & 0.0251 & & \\
M3 & & 3 & 0.0322 & & \\
M4 & & 20 & 0.113 & & \\
M5 & & & & & \\
\hline
\end{tabular}

in year 2100, such that cumulative $\mathrm{CO}_{2}$ emissions were $1000 \mathrm{Pg} \mathrm{C}$.

Within each suite ( $\mathrm{S}$ and $\mathrm{M}$ ), we carried out six simulations, each with an increasing sensitivity of $\mathrm{CaCO}_{3}$ production to changes in $\Omega_{\mathrm{CaCO}_{3}}$ (Fig. 1). In the standard model configuration (as described above), $\mathrm{CaCO}_{3}$ production is independent of saturation state and the PIC:POC production ratio used in the calculation of $\mathrm{CaCO}_{3}$ production is fixed at a value of 0.018 . This configuration was used for the "control" simulations S0 and M0 (see Table 1) and represents only the temperature effect on $\mathrm{CaCO}_{3}$ production (Schmittner et al., 2008). In the simulations with $\mathrm{CaCO}_{3}$ productionsaturation state dependence (S1 to S5 and M1 to M5 in Table 1), we introduced a Michaelis-Menten function to calculate the $\mathrm{CaCO}_{3}$ :nondiazotrophic detritus production ratio (PIC:POC) as a function of saturation state $(\Omega)$ :

$$
\left(\frac{\mathrm{PIC}}{\mathrm{POC}}\right)=\left(\frac{\mathrm{PIC}}{\mathrm{POC}}\right)_{\max } \cdot\left(\frac{(\Omega-1)}{K_{\max }+(\Omega-1)}\right)
$$

In this relationship, $(\mathrm{PIC} / \mathrm{POC})_{\max }$ is a specified maximum production ratio and $K_{\max }$ is a half-saturation constant defining the value of $(\Omega-1)$, for which PIC/POC equals one half of (PIC/POC) $)_{\max }$ (Gehlen et al., 2007).

Table 1 summarizes the values of (PIC:POC) $\max$ and $K_{\max }$ used for each model version. We selected values of $K_{\max }$ ranging from 0.07 to 20 for each scenario in order to vary the shape of the PIC:POC vs. $\Omega_{\mathrm{CaCO}_{3}}$ function between no PIC:POC- $\Omega_{\mathrm{CaCO}_{3}}$ response (scenario 0) to a near linear response (scenario 5), as illustrated in Fig. 1. In order to keep the global preindustrial PIC:POC production ratio the same in all models, we back-calculated the value for (PIC:POC) $)_{\max }$ in each scenario using the global mean preindustrial sea-surface calcite saturation state value of 4.78 from the standard model. In the subsequent transient simulations, changes to the PIC:POC production ratio over time brought about by ocean acidification varied according to the imposed calcification sensitivities.

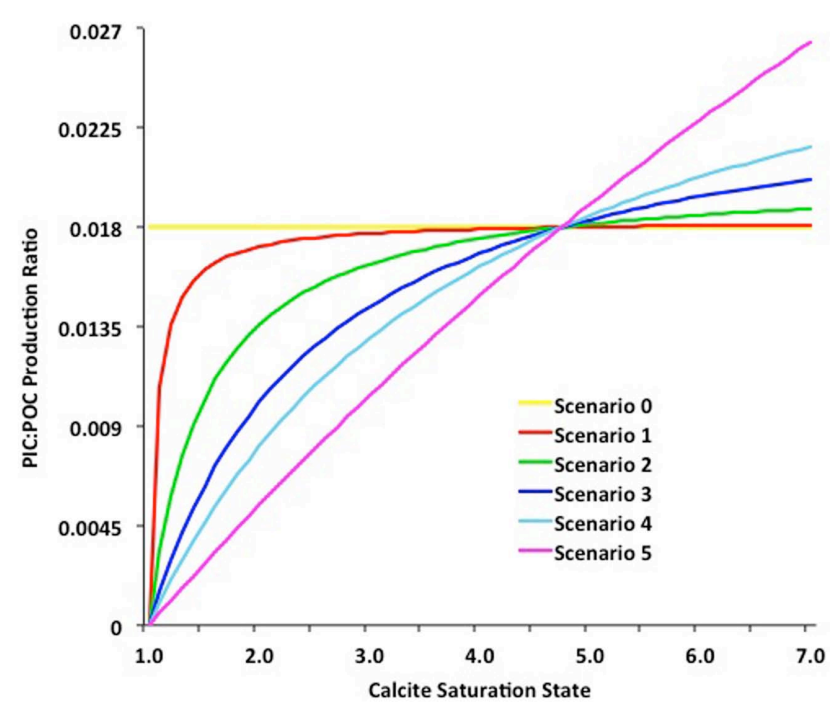

Fig. 1. $\mathrm{CaCO}_{3}$ :particulate organic carbon production ratio dependence on calcite saturation state.

\section{Results}

\subsection{Model-observation comparison}

The standard version of the model simulated a $\mathrm{CaCO}_{3}$ production rate of $0.6 \mathrm{Pg} \mathrm{C} \mathrm{yr}^{-1}$ in the year 2000 . This is consistent with the estimate of $0.6-1.6 \mathrm{Pg} \mathrm{Cyr}^{-1}$ based on satellite and sediment trap data and of $0.4-1.8 \mathrm{Pg} \mathrm{C} \mathrm{yr}^{-1}$ based on model predictions (Doney et al., 2009). The rain ratio of $\mathrm{CaCO}_{3}$ :POC across $130-\mathrm{m}$ depth for all six model configurations in the year 2000 is shown in Fig. 2. The global mean rain ratio for all six model configurations is 0.06 which is consistent with observational estimates of $0.06 \pm 0.03$ (Sarmiento et al., 2002) and is comparable to the range of 0.07-0.11 established in other studies (Lee, 2001; Jin et al., 2006). The mean rain ratio across the Atlantic, Pacific, and 


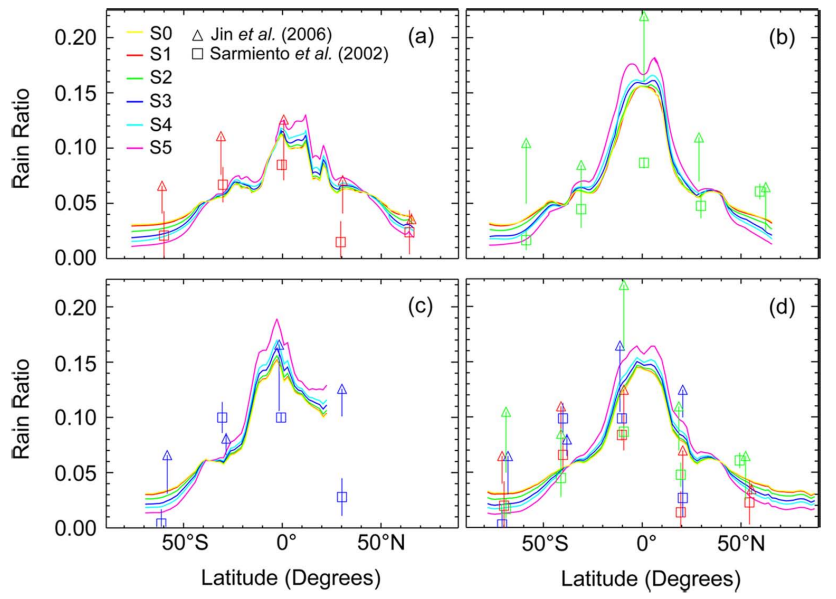

Fig. 2. Zonally averaged $\mathrm{CaCO}_{3}$ :particulate organic carbon flux (rain ratio) across $130 \mathrm{~m}$ depth in comparison with observational estimates from Sarmiento et al. (2002) (square symbols) and Jin et al. (2006) (triangles) including their reported error bars (vertical lines) for the (a) Atlantic, (b) Pacific, and (c) Indian Oceans as well as (d) the global model mean.

Indian Oceans is also consistent with observational estimates (Sarmiento et al., 2002; Jin et al., 2006). Overall, the rain ratio exhibits a strong latitudinal dependence with lower global mean ratios at high latitudes. This variation with latitude is dominated by the temperature effect on recycling, as indicated by the relatively small differences between the six saturation state-dependent scenarios. Nonetheless, increasing sensitivity of $\mathrm{CaCO}_{3}$ production to $\Omega_{\mathrm{CaCO}_{3}}$ increases the variation of the rain ratio with latitude. However, the errors and differences between the observational estimates are typically larger than the differences between the different model configurations in this study, which make it difficult to identify which model versions best reflect the observational data.

Higher rain ratios at low latitudes lead to more efficient removal of alkalinity from the tropical surface ocean (Fig. 3). The control run (S0) captures the spatial patterns of high surface potential alkalinity at high latitudes and along the eastern boundary of the Pacific and low values elsewhere, where potential alkalinity is defined as the alkalinity corrected for biological activity and normalized for salinity (Brewer and Goldman, 1976). The gradient between high and low areas of potential alkalinity, however, is larger in the model compared to observations. Furthermore, models with high sensitivity of $\mathrm{CaCO}_{3}$ production to $\Omega_{\mathrm{CaCO}_{3}}$ tend to have a larger difference in rain ratio between high and low latitudes thereby decreasing the agreement with GLODAP observations (Key et al., 2004).

A comparison of modelled ocean alkalinity and DIC in the year 1995 with gridded data sets based on field measurements in the 1990s (Key et al., 2004) is shown in Fig. 4. The UVic model version 2.9 contains an average of $59 \mathrm{mmol} \mathrm{m}^{-3}$ more alkalinity than the observations, due to errors in the

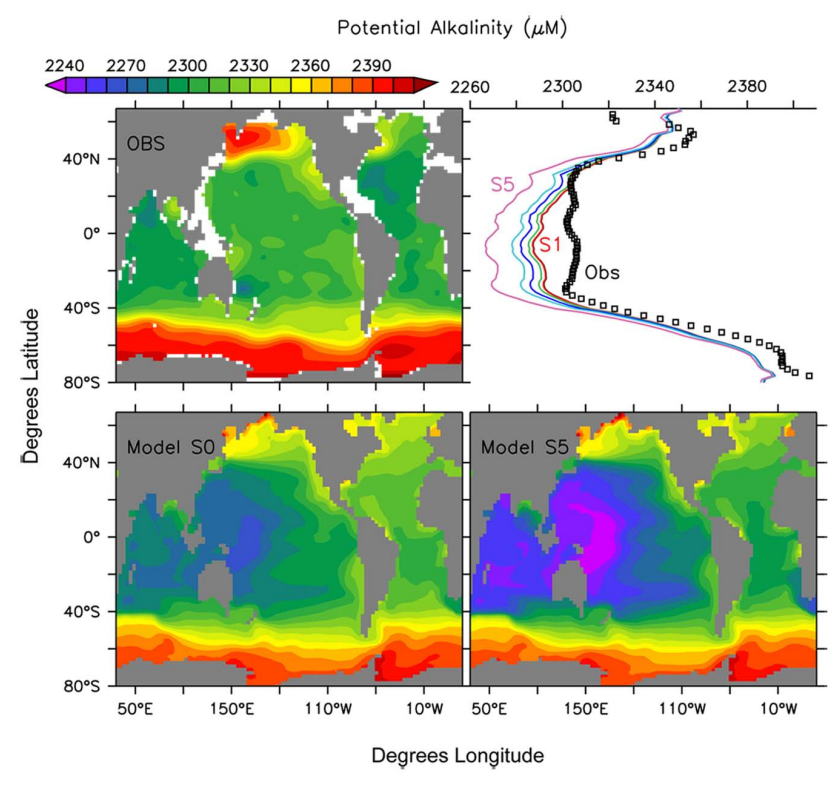

Fig. 3. Comparison of observed (top left) and modelled (bottom) surface distributions of potential alkalinity. The top right panel shows zonally averaged values for the Key et al. (2004) GLODAP observations (squares) and the different models (coloured lines). Note that the black line representing model S0 is overlain by the red line representing model $\mathrm{S} 1$, because both are almost undistinguishable.

burial flux of $\mathrm{CaCO}_{3}$. In addition, the model simulates a somewhat stronger alkalinity pump than observed, evidenced by high simulated alkalinity in the deep North Pacific. There is little difference between the standard configuration of the model (run S0) and the extreme calcification sensitivity configuration (run S5) relative to both each other and GLODAP observations. Run S5 has higher alkalinity values in the deep ocean, particularly in the Northern Hemisphere, increasing the difference with the observations compared to run S0. In Southern Ocean bottom waters, on the other hand, values are lower and in better agreement with the observations compared to S0. Zonally averaged DIC concentrations are almost indistinguishable in the different models.

\subsection{Future changes in the surface ocean}

In the standard "business as usual" simulation (run S0), total ocean carbon increased by $517 \mathrm{Pg} \mathrm{C}$ by 2100 , resulting in maximum decreases of globally averaged surface $\mathrm{pH}$ and surface $\Omega_{\mathrm{CaCO}_{3}}$ of 0.397 and 2.34 respectively near year 2100 (Fig. 5). In the standard "mitigation" run M0, the reductions of sea surface $\mathrm{pH}$ and $\Omega_{\mathrm{CaCO}_{3}}$ were much less, reaching maximum decreases of 0.175 and 1.19 respectively relatively near 2100 (Fig. 5). In both cases, after $\mathrm{CO}_{2}$ emissions ceased in the year 2100 , ocean surface $\mathrm{pH}$ and saturation state rapidly stabilized and began slow recoveries in response to declining atmospheric $\mathrm{CO}_{2}$. Despite this recovery 

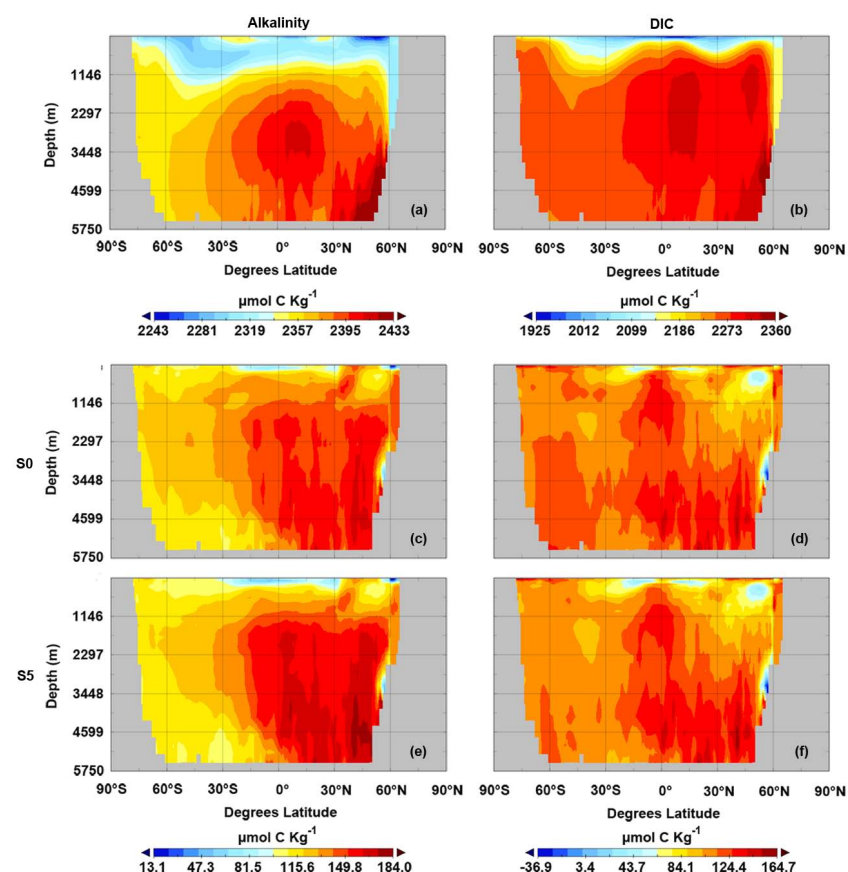

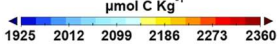
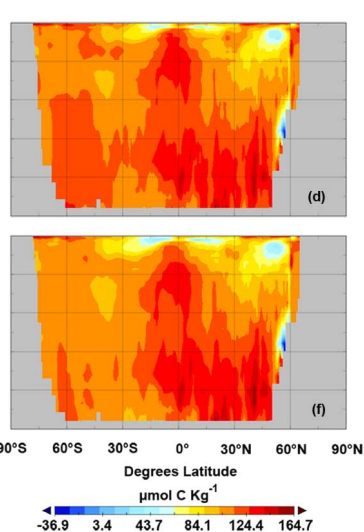

Fig. 4. Observed (a) ocean alkalinity and (b) dissolved inorganic carbon (Key et al., 2004). Panels (c) and (e) are plots of the difference between the zonally averaged global ocean alkalinity model output in year 1995 and observations for runs S0 and S5 respectively. Panels (d) and (f) are plots of the difference between the zonally averaged global dissolved inorganic carbon model output in year 1995 and observations for runs S0 and S5 respectively.

in in both sea surface $\mathrm{pH}$ and $\Omega_{\mathrm{CaCO}_{3}}$, however, high latitude surface waters came very close to undersaturated levels $\left(\Omega_{\mathrm{CaCO}_{3}}<1\right)$, particularly under business-as-usual $\mathrm{CO}_{2}$ emissions (Fig. 6). By the year 3500, surface $\mathrm{pH}$ and $\Omega_{\mathrm{CaCO}_{3}}$ still remained below preindustrial levels in all simulations suggesting that, even in the case of low $\mathrm{CO}_{2}$ emissions, the legacy of anthropogenic $\mathrm{CO}_{2}$ will stretch for millennia after $\mathrm{CO}_{2}$ emissions end.

For the remainder of the discussion, with the exception of $\mathrm{CaCO}_{3}$ sediment burial in Sect. 3.4, we focus only on the business-as-usual simulations, given that the mitigation runs generally show the same patterns of variability but with smaller magnitudes, though information for both suites of simulations is shown in the tables.

Varying the sensitivity of $\mathrm{CaCO}_{3}$ production to decreasing $\Omega_{\mathrm{CaCO}_{3}}$ had a dramatic effect on the response of $\mathrm{CaCO}_{3}$ production rates to increased ocean carbon uptake. In the run with no dependence on saturation state (S0), the $\mathrm{CaCO}_{3}$ production rate increased by $0.13 \mathrm{PgC}^{-1}$ relative to preindustrial by year 2100 and reached a maximum increase of $\sim 0.18 \mathrm{Pg} \mathrm{C} \mathrm{yr}^{-1}$ around the year $2550, \sim 20 \%$ higher than preindustrial production rates (Fig. 7). In contrast, the strongest response to acidification (S5) caused an opposite response, with $\mathrm{CaCO}_{3}$ production decreasing by almost $0.3 \mathrm{Pg} \mathrm{C} \mathrm{yr}^{-1}$ near year 2100 , a decrease of more than
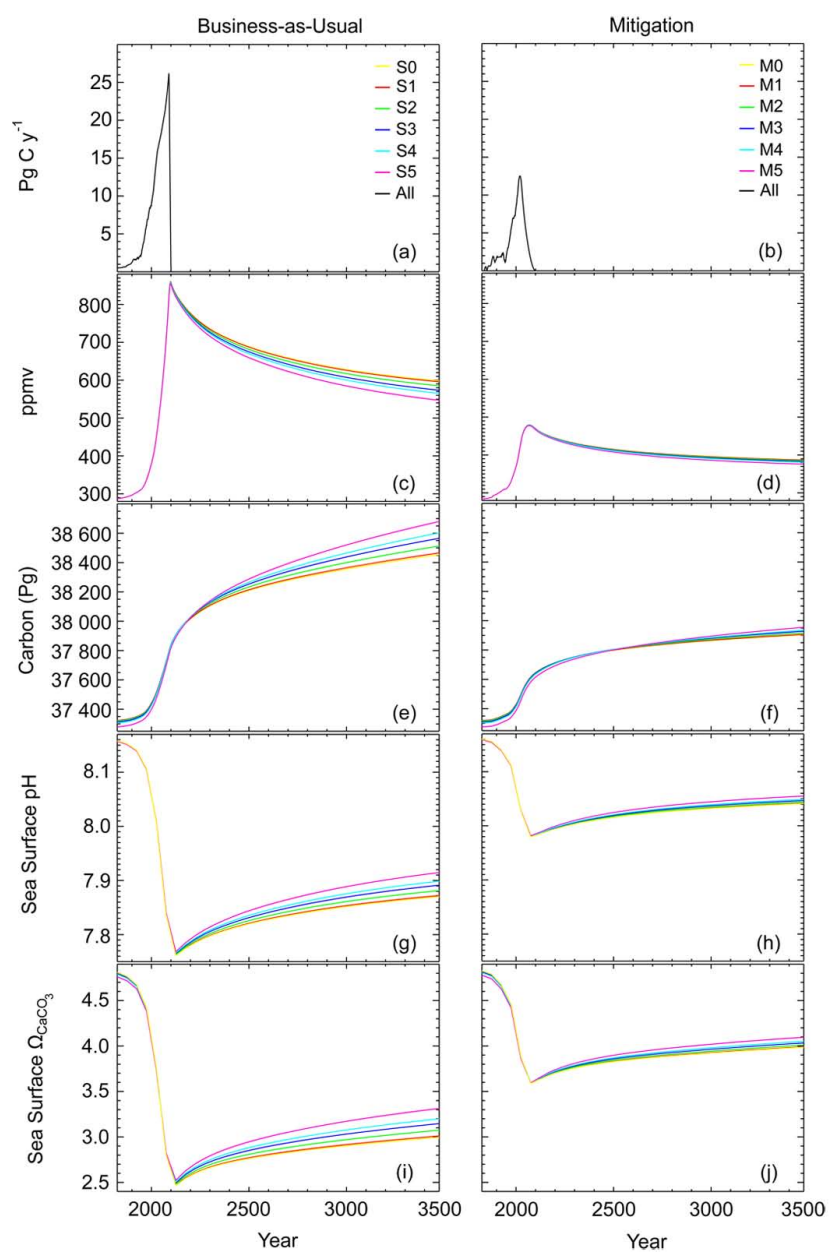

Fig. 5. (a, b) Change in anthropogenic $\mathrm{CO}_{2}$ emissions, (c, d) globally averaged atmospheric $\mathrm{CO}_{2}$ concentration, $(\mathbf{e}, \mathbf{f})$ globally averaged ocean carbon, $(\mathbf{g}, \mathbf{h})$ globally averaged sea surface $\mathrm{pH}$, and (i, j) globally averaged calcite saturation state under a "business-asusual" (Suite $\mathrm{S}$ ) and a "mitigation" $\mathrm{CO}_{2}$ emissions scenario (Suite $\mathrm{M})$ respectively.

$30 \%$. Between years 2100 and 3500 , the $\mathrm{CaCO}_{3}$ production rate slowly recovered, increasing by $0.16 \mathrm{PgC}^{-1}$, but still fell short of the preindustrial production rate. Simulation S3, however, with an intermediate dependence on saturation state, produced a cancellation between the temperature and acidification responses leading to a near-constant production rate of $\mathrm{CaCO}_{3}$.

\subsection{Future changes in the water column}

In simulations that included an acidification sensitivity (S1S5), decreased $\mathrm{CaCO}_{3}$ production led to weaker vertical gradients of alkalinity and DIC with increased concentrations at the surface and decreased concentrations at depth relative to control (Fig. 8). The greatest increases in alkalinity and DIC occurred in the thermocline and throughout the water column in the Arctic Ocean. Throughout most of the ocean, DIC and 


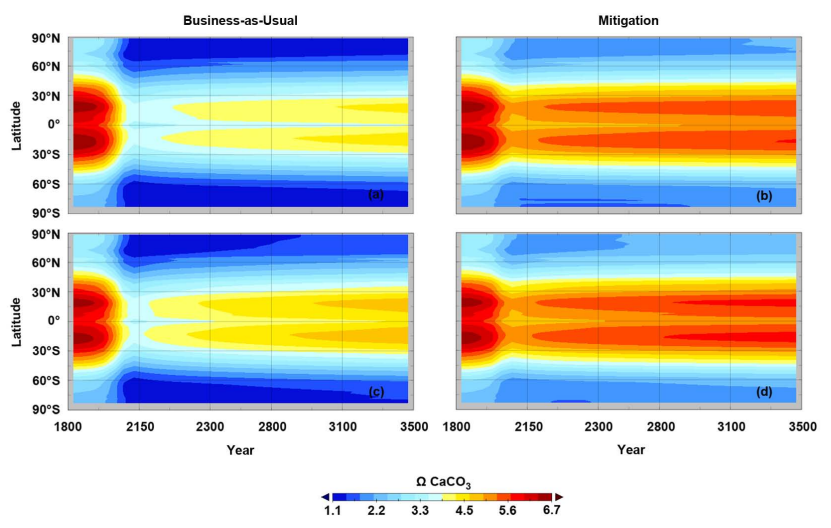

Fig. 6. Evolution of sea surface calcite saturation state over time as a function of latitude for (a) run S0, (b) run M0, (c) run S5, and (d) run M5 respectively.
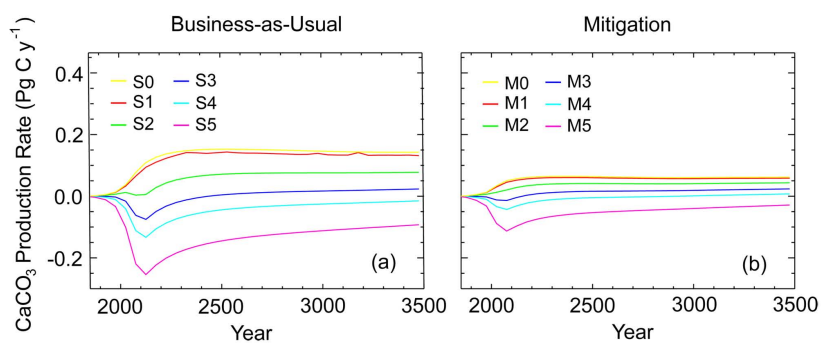

Fig. 7. Change in total sea surface $\mathrm{CaCO}_{3}$ production rate under (a) a "business-as-usual" $\mathrm{CO}_{2}$ emissions scenario (Suite $\mathrm{S}$ ) and (b) under a "mitigation" $\mathrm{CO}_{2}$ emissions scenario (Suite $\mathrm{M}$ ).

alkalinity decreased at depth as a result of decreased export of particulate inorganic carbon to the deep ocean, with the largest decreases evident at around $60^{\circ} \mathrm{S}$ and $45^{\circ} \mathrm{N}$.

As shown in Fig. 9, by year 3500 the percent of total global ocean waters undersaturated with respect to calcite increased by $25.4 \%$ in control run S0 and by $24.6 \%$ in run S5 relative to preindustrial times. The difference in the volume of water where $\Omega_{\mathrm{CaCO}_{3}}<1$ between runs is small, because the net changes in total ocean alkalinity between runs are very small relative to the total ocean alkalinity pool (Table 2). By the year 3500 , the simulations show a large volume of the subsurface ocean falling below calcite saturation $\left(\Omega_{\mathrm{CaCO}_{3}}<1\right)$, extending to about $500 \mathrm{~m}$ depth in the equatorial region and in the high latitude Southern Oceans in the zonal average (Fig. 10). Compared to the control simulation (S0), runs with acidification-sensitive calcification showed more severe undersaturation developing in the deep sea, and reduced acidification throughout the thermocline, due to weakening of the alkalinity pump.

\subsection{Future changes to marine sediments}

The sedimentary $\mathrm{CaCO}_{3}$ pool also responded to the calcifier sensitivity to acidification, affecting the global alkalinity
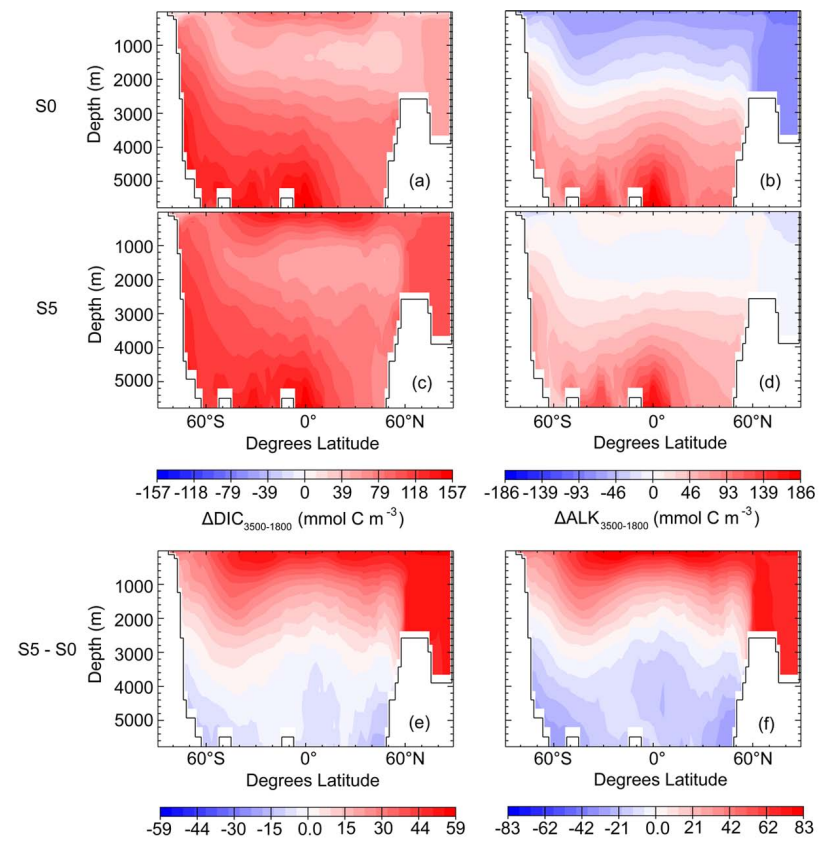

$\triangle \mathrm{DIC}_{3500-1800}$ relative to control ( $\left.\mathrm{mmol} \mathrm{C} \mathrm{m}^{-3}\right) \quad \triangle \mathrm{ALK}_{3500-1800}$ relative to control( $\mathrm{mmol} \mathrm{C} \mathrm{m}^{-3}$ )

Fig. 8. (a) Global zonally averaged $\triangle D C_{3500-1800}$ for run S0, (b) the global zonally averaged $\triangle \mathrm{ALK}_{3500-1800}$ for run $\mathrm{S} 0$, (c) the global zonally averaged $\triangle \mathrm{DIC}_{3500-1800}$ for run S5, (d) the global zonally averaged $\Delta \mathrm{ALK}_{3500-1800}$ for run S5, (e) the difference in global zonally averaged $\Delta \mathrm{DIC}_{3500-1800}$ relative to control (S0) for run S5, and (f) the difference in global zonally averaged $\triangle \mathrm{ALK}_{3500-1800}$ relative to control (S0) for run S5.
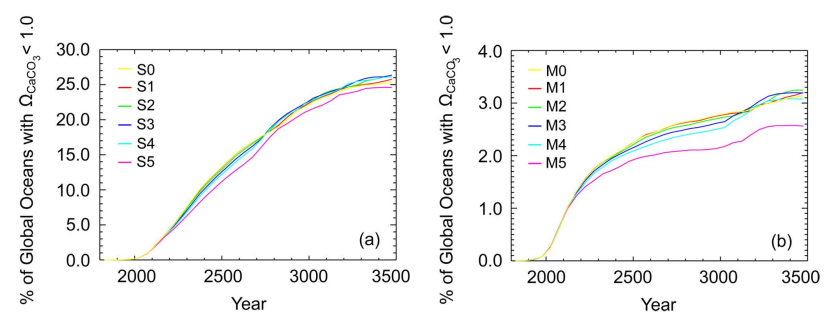

Fig. 9. Plot of the change in the percent of global oceans undersaturated with respect to calcite relative to preindustrial times under (a) a "business-as-usual" $\mathrm{CO}_{2}$ emissions scenario (Suite $\mathrm{S}$ ) and (b) under a "mitigation" $\mathrm{CO}_{2}$ emissions scenario (Suite $\mathrm{M}$ ).

inventory. In the control run, the PIC:POC rain ratio at the ocean sediments rose over time as a result of temperature effect on $\mathrm{CaCO}_{3}$ production rates (Fig. 11). This rise was dampened by increasing sensitivity of calcification to acidification, with the most sensitive runs (S4 and S5) showing temporary decreases in the rain ratio below the initial rain ratio peaking in year 2100 . But despite any increases in the rain ratio, the global mass of $\mathrm{CaCO}_{3}$ sediment in the bioturbated layer decreased in all cases relative to preindustrial times (Fig. 11, Table 4), due to dissolution by acidic bottom waters. The burial rate of $\mathrm{CaCO}_{3}$ sediments decreased with 
Table 2. Summary of the change in atmospheric and ocean output for years $1800-3500$ for Suite $S$ simulations. Values in column $S 0_{1800}$ represent absolute output in the base model in year 1800. Subsequent columns show differences from 1800 to 3500 for each calcification sensitivity (S0 to S5).

\begin{tabular}{|c|c|c|c|c|c|c|c|}
\hline & $\mathrm{S}_{1800}$ & $\mathrm{~S}_{3500-1800}$ & $\mathrm{~S}_{3500-1800}$ & $\mathrm{~S} 23500-1800$ & $\mathrm{~S} 33500-1800$ & $\mathrm{~S} 43500-1800$ & $\mathrm{~S}_{3500-1800}$ \\
\hline $\mathrm{CaCO}_{3}$ Production Rate $\left(\mathrm{Pg} \mathrm{C} \mathrm{yr}^{-1}\right)$ & 0.572 & 0.143 & 0.132 & 0.0776 & 0.0235 & -0.0150 & -0.0926 \\
\hline Sea Surface Alkalinity $(\operatorname{Pg} C)$ & 175 & -5.23 & -4.98 & -3.94 & -2.71 & -1.76 & 0.340 \\
\hline Sea Surface DIC (Pg C) & 152 & 4.44 & 4.61 & 5.30 & 6.13 & 6.76 & 8.16 \\
\hline Sea Surface $p \mathrm{CO}_{2}(\mathrm{ppmv})$ & 293 & 316 & 313 & 302 & 290 & 281 & 263 \\
\hline Total Ocean Alkalinity (Pg C) & 39495 & 39.1 & 48.6 & 97.2 & 157 & 203 & 319 \\
\hline Total Ocean Carbon (Pg C) & 37321 & 1138 & 1150 & 1200 & 1260 & 1305 & 1410 \\
\hline Total Atmospheric Carbon (Pg C) & 602 & 667 & 661 & 637 & 612 & 594 & 556 \\
\hline Sea Surface Calcite Saturation State & 4.81 & -1.81 & -1.79 & -1.73 & -1.65 & -1.59 & -1.45 \\
\hline Sea Surface $\mathrm{pH}$ & 8.16 & -0.288 & -0.286 & -0.277 & -0.267 & -0.259 & -0.242 \\
\hline
\end{tabular}
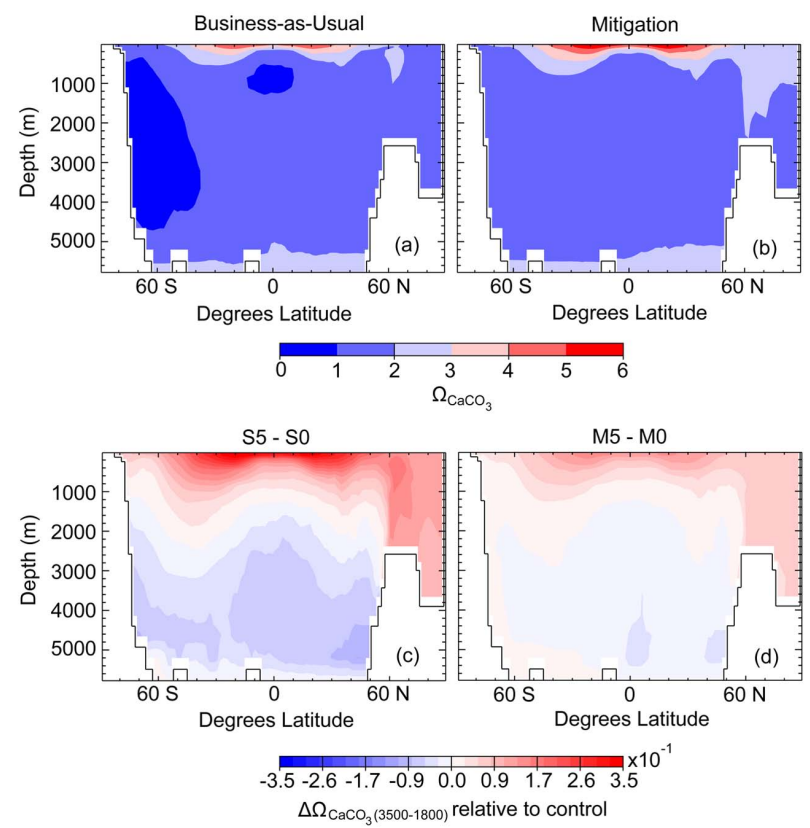

Fig. 10. Global zonally averaged ocean calcite saturation state in year 3500 for (a) run S0 and (b) run M0 and the global zonally averaged change in $\Delta \Omega_{\mathrm{CaCO}_{3}(3500-1800)}$ relative to control (scenario 0 ) for (c) run S5 and (d) run M5 respectively.

increasing sensitivity of calcifiers to acidification because of the relatively smaller flux of $\mathrm{CaCO}_{3}$ to the sediments. In the mitigation scenarios (M1-M5), however, $\mathrm{CaCO}_{3}$ sequestration in deeper sediments showed a different trend and increased by up to $33.0 \mathrm{Pg} \mathrm{C}$ relative to control (Fig. 11, Table 5). Increasing sensitivity of $\mathrm{CaCO}_{3}$ production rates to $\Omega_{\mathrm{CaCO}_{3}}$ in these scenarios led to faster recovery of $\Omega_{\mathrm{CaCO}_{3}}$, $\mathrm{pH}$, and sea-surface $\mathrm{CaCO}_{3}$ production/export (Figs. 5 and 7), which led to increased $\mathrm{CaCO}_{3}$ burial, despite the opposing influence of decreased rain ratio. Consequently, $\mathrm{CaCO}_{3}$ in the bioturbated layer was still slightly decreased relative to control due to a smaller rain ratio, but the net burial of $\mathrm{CaCO}_{3}$ in deeper sediments increased with increasing sensitivity of $\mathrm{CaCO}_{3}$ production to $\Omega_{\mathrm{CaCO}_{3}}$ relative to control in the M-simulations.
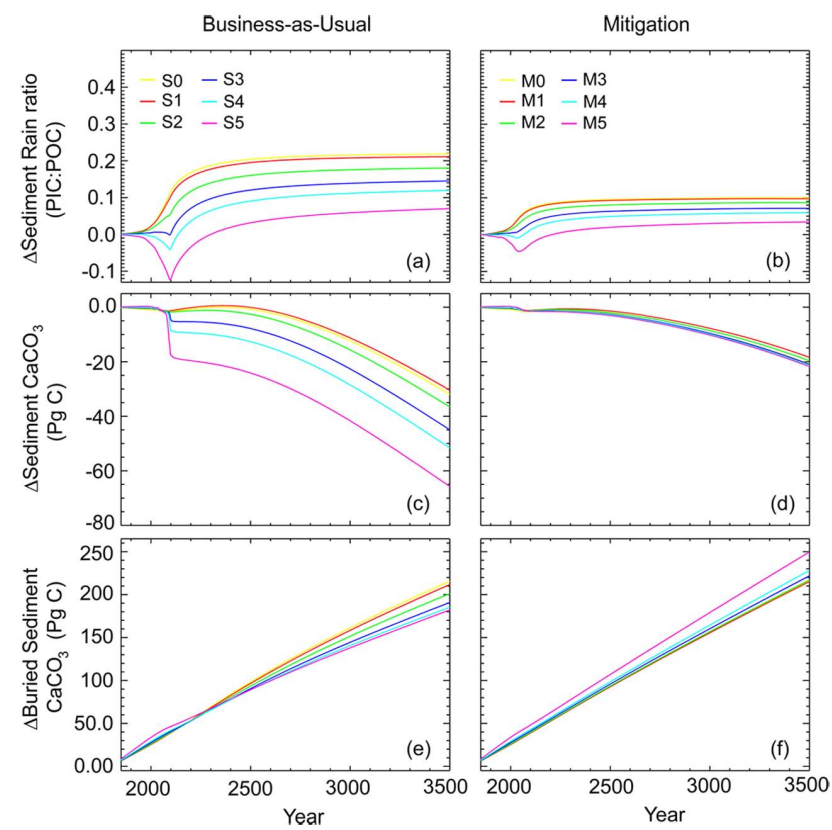

Fig. 11. (a, b) Change in globally averaged sediment rain ratio, (c, d) the total $\mathrm{CaCO}_{3}$-carbon in the sediment bioturbated layer, (e, f) and the total $\mathrm{CaCO}_{3}$ buried in deeper marine sediments under a "business-as-usual" and a "mitigation" $\mathrm{CO}_{2}$ emissions scenario respectively.

\section{Discussion}

\section{1 $\mathrm{CaCO}_{3}$ production rates}

In the absence of the $\Omega_{\mathrm{CaCO}_{3}}$ effect (runs S0 and M0), $\mathrm{CaCO}_{3}$ production increased proportionally with the temperaturedependent primary production rate, as shown also by Schmittner et al. (2008). This occurs despite a small decrease in the globally averaged surface $\mathrm{PO}_{4}$ concentration (not shown) due to greater recycling of nutrients and higher intrinsic growth rates (Eppley, 1972). In model configurations 1 and 2 , the sensitivity of $\mathrm{CaCO}_{3}$ production rates to changes in $\Omega_{\mathrm{CaCO}_{3}}$ was not high enough to completely counteract 
Table 3. Summary of the change in atmospheric and ocean output for years $1800-3500$ for Suite $M$ simulations. Values in column $M 0_{1800}$ represent absolute output in the base model in year 1800. Subsequent columns show differences from 1800 to 3500 for each calcification sensitivity (M1 to M5).

\begin{tabular}{|c|c|c|c|c|c|c|c|}
\hline & $\mathrm{M}_{1800}$ & $\mathrm{M}_{3500-1800}$ & $\mathrm{M}_{3500-1800}$ & $\mathrm{M} 23500-1800$ & $\mathrm{M} 33500-1800$ & $\mathrm{M} 43500-1800$ & M5 $3500-1800$ \\
\hline $\mathrm{CaCO}_{3}$ Production Rate $\left(\mathrm{Pg} \mathrm{Cyr}^{-1}\right)$ & 0.572 & 0.0615 & 0.0585 & 0.0436 & 0.0237 & 0.00752 & -0.0286 \\
\hline Sea Surface Alkalinity $(\operatorname{PgC})$ & 175 & -2.31 & -2.24 & -1.95 & -1.53 & -1.17 & -0.228 \\
\hline Sea Surface DIC (Pg C) & 152 & 1.97 & 2.02 & 2.21 & 2.48 & 2.70 & 3.31 \\
\hline Sea Surface $p \mathrm{CO}_{2}(\mathrm{ppmv})$ & 293 & 104 & 103 & 102 & 99.4 & 97.4 & 92.4 \\
\hline Total Ocean Alkalinity (Pg C) & 39495 & 15.3 & 17.9 & 32.4 & 53.4 & 72.0 & 130 \\
\hline Total Ocean Carbon $(\mathrm{PgC})$ & 37321 & 584 & 587 & 600 & 619 & 634 & 681 \\
\hline Total Atmospheric Carbon (Pg C) & 602 & 219 & 218 & 215 & 210 & 206 & 195 \\
\hline Sea Surface Calcite Saturation State & 4.81 & -0.841 & -0.835 & -0.813 & -0.782 & -0.755 & -0.684 \\
\hline Sea Surface $\mathrm{pH}$ & 8.16 & -0.119 & -0.119 & -0.117 & -0.114 & -0.111 & -0.104 \\
\hline
\end{tabular}

this temperature effect. Thus, although reduced relative to control, $\mathrm{CaCO}_{3}$ production rates in these configurations increased between years 1800 and 2100 despite increasing ocean acidification. Though the UVic ESCM does account for decreased nutrient supply in a warming and more stratified ocean (Schmittner et al., 2005b), the increase in primary production in the UVic ESCM runs contrary to the decrease in primary production under a warming climate in the model ensemble assessed by Steinacher et al. (2010). However, the increases in primary production with sea surface temperature simulated by the UVic ESCM in Schmittner et al. (2008) and this study (not shown) in the 21 st century are small. The bulk of the increase in primary production occurs post-21st century when sufficient time has passed for the subsurface waters to warm, which leads to a less stratified vertical temperature profile and removes some of the nutrient limitation on primary production (and calcification).

In configurations $3-5$, the sensitivity of $\mathrm{CaCO}_{3}$ production rates to changes in $\Omega_{\mathrm{CaCO}_{3}}$ was high enough to counteract this temperature effect, resulting in decreases in $\mathrm{CaCO}_{3}$ production rates ranging from $12.7 \%$ to $39.2 \%$ between years 1800 and 2100. Although not directly comparable due to differences in the underlying $\mathrm{CO}_{2}$ emissions scenarios and simulation durations, these decreases are similar to the predicted decreases in $\mathrm{CaCO}_{3}$ production of $27 \%$ by Gehlen et al. (2007) and of $38 \%$ by Heinze (2004) when $p \mathrm{CO}_{2}$ reached approximately $1000 \mathrm{ppm}$. Additionally, our results are similar to the $20-34 \%$ reduction in $\mathrm{CaCO}_{3}$ production by the year 2100 predicted by Gangst $\varnothing$ et al. (2011) under the IPCC RCP8.5 $\mathrm{CO}_{2}$ emissions scenario ( $p \mathrm{CO}_{2} \approx 800 \mathrm{ppm}$ ). Ridgwell et al. (2007b), however, predicted a much larger $60 \%$ reduction in $\mathrm{CaCO}_{3}$ production when atmospheric $p \mathrm{CO}_{2}$ reached approximately $1000 \mathrm{ppm}$, though the slow recovery of calcification rates after the cessation of anthropogenic $\mathrm{CO}_{2}$ emissions is similar to that predicted in this study. Aside from methodological differences, the much lower reduction in calcification rates predicted in this study relative to Ridgwell et al. (2007b) is due, at least in part, to the temperature effect on phytoplankton growth rates partially offsetting the acidification-driven decrease in calcification.
The $\mathrm{CaCO}_{3}$ pump representation in the UVic ESCM is fairly simple (e.g. there is no distinction between the different polymorphs of $\mathrm{CaCO}_{3}$ ). Nonetheless, the results generally agree with other similar studies in that decreasing calcification rates lead to an increase in the strength of $\mathrm{CO}_{2-}$ calcification feedback, to a degree dependent on the sensitivity of calcifiers to saturation state. By the year 2100 , the strength of the $\mathrm{CO}_{2}$-calcification feedback ranged between $0.45-12.3 \mathrm{PgC}$ for runs $\mathrm{S} 1-\mathrm{S} 5$ relative to control (S0) at an atmospheric $p \mathrm{CO}_{2}$ of $\sim 850 \mathrm{ppm}$. This range, however, is somewhat smaller than the $2.12-23.3 \mathrm{Pg} \mathrm{C}$ predicted by Gangst $\varnothing$ et al. (2011) at an atmospheric $p \mathrm{CO}_{2} \sim$ $800 \mathrm{ppm}$ and the 5.4-25.7 Pg C predicted by Ridgwell et al. (2007b) at an atmospheric $p \mathrm{CO}_{2} \sim 1000 \mathrm{ppm}$. Neglecting the runs where the temperature effect on phytoplankton growth rates completely offsets the acidification effect on calcification (runs $\mathrm{S} 1$ and $\mathrm{S} 2$ ), this range can be truncated to 5.4-12.3 Pg C, which falls within the $\mathrm{CO}_{2}$-calcification feedback ranges reported by both Gangst $\varnothing$ et al. (2011) and Ridgwell et al. (2007b).

The important dynamic highlighted here - the opposing effects of increasing growth rates vs. decreasing calcification - depends equally on the complex response of ocean ecosystems to the recycling of nutrients in the surface layer, and the myriad controls on export. It is difficult to evaluate to what degree the model represents these processes properly, given the current state of understanding, but it is also certain to vary between models. Tentative comparison to surface potential alkalinity observations (Fig. 3), where ocean alkalinity is only affected by $\mathrm{CaCO}_{3}$ production and dissolution, indicates that these observations could be used in the future to better constrain the relative importance of the temperature vs. the acidification effect. Our results emphasize that temperature-driven changes may be of equal or greater importance to acidification in determining future pelagic $\mathrm{CaCO}_{3}$ production. 
Table 4. Summary of the change in rain ratio and sediment output for years $1800-3500$ for Suite $\mathrm{S}$ simulations. Values in column $\mathrm{S} 0_{1800}$ represent absolute output in the base model in year 1800. Subsequent columns show differences from 1800 to 3500 for each calcification sensitivity (S0 to S5).

\begin{tabular}{|c|c|c|c|c|c|c|c|}
\hline & $\mathrm{S}_{1800}$ & $\mathrm{~S}_{3500-1800}$ & $\mathrm{~S} 1_{3500-1800}$ & $\mathrm{~S} 23500-1800$ & $\mathrm{~S} 33500-1800$ & $\mathrm{~S} 43500-1800$ & $\mathrm{~S} 53500-1800$ \\
\hline Rain Ratio Reaching Sediments (PIC:POC) & 1.25 & 0.219 & 0.212 & 0.201 & 0.145 & 0.120 & 0.0699 \\
\hline Total $\mathrm{CaCO}_{3}$ in Sediment Bioturbated Layer $(\mathrm{Pg} \mathrm{C})$ & 1095 & -32.0 & -32.4 & -36.5 & -44.9 & -51.6 & -65.7 \\
\hline Additional $\mathrm{CaCO}_{3}$ Buried in Sediments $(\mathrm{PgC})$ & & 11.4 & 7.4 & -3.6 & -13.6 & -19.6 & -22.6 \\
\hline
\end{tabular}

Table 5. Summary of the change in rain ratio and sediment output for years $1800-3500$ for Suite $M$ simulations. Values in column $M 0_{1800}$ represent absolute output in the base model in year 1800. Subsequent columns show differences from 1800 to 3500 for each calcification sensitivity (M0 to M5).

\begin{tabular}{|c|c|c|c|c|c|c|c|}
\hline & $\mathrm{M} 0_{1800}$ & $\mathrm{M} 0_{3500-1800}$ & $\mathrm{M}_{3500-1800}$ & $\mathrm{M} 23500-1800$ & M33500-1800 & $\mathrm{M} 43500-1800$ & $\mathrm{M}_{3500-1800}$ \\
\hline Rain Ratio Reaching Sediments (PIC:POC) & 1.25 & 0.0996 & 0.0973 & 0.0863 & 0.0713 & 0.0592 & 0.0342 \\
\hline Total $\mathrm{CaCO}_{3}$ in Sediment Bioturbated Layer $(\operatorname{Pg} \mathrm{C})$ & 1095 & -20.8 & -18.4 & -19.6 & -21.0 & -21.5 & -21.8 \\
\hline Additional $\mathrm{CaCO}_{3}$ Buried in Sediments $(\mathrm{PgC})$ & & 12.4 & 10.4 & 12.4 & 17.4 & 23.4 & 45.4 \\
\hline
\end{tabular}

\subsection{Global carbon reservoirs}

In our simulations, carbon is redistributed differently amongst the atmospheric, ocean, and sediment reservoirs dependent on the varying $\mathrm{CaCO}_{3}$ production rates. In all simulations, decreasing $\mathrm{CaCO}_{3}$ production rates resulted in greater carbon uptake by the ocean and a reduced airborne fraction of carbon. Between years 1800 and 3500, atmospheric $p \mathrm{CO}_{2}$ decreased by $2.81-52.2$ ppmv in runs $\mathrm{S} 1-\mathrm{S} 5$ (and by 0.377-11.2 ppmv in runs M1-M5) relative to control, a similar magnitude to that estimated by Barker et al. (2003), Heinze (2004), Gehlen et al. (2007). It is interesting to note that the net increase of the ocean carbon reservoir exceeds the decrease of the atmospheric carbon reservoir (Tables 2 and 3 ). The carbon that makes up the difference originates from the terrestrial and marine sediment carbon reservoirs. The sediment reservoir, in particular, adds carbon to the ocean due to $\mathrm{CaCO}_{3}$-sediment dissolution. This highlights the importance of including inter-active terrestrial carbon and sediment carbon components when assessing the $\mathrm{CO}_{2}-\mathrm{CaCO}_{3}$ climate feedback.

The mass of $\mathrm{CaCO}_{3}$ in the sediment bioturbated layer showed the sharpest decrease relative to control (S0) around the year 2100 when surface ocean $\mathrm{CaCO}_{3}$ production and PIC:POC rain ratios were at their lowest values (Figs. 7 and 11). This decrease at peak emissions was followed by a more gradual decrease reaching a minimum in year 3500 in all runs. This continued decrease in sedimentary $\mathrm{CaCO}_{3}$ between years 2100 and 3500 , when sea surface calcification rates were recovering, highlights how invasion of anthropogenic $\mathrm{CO}_{2}$ via large-scale ocean circulation can affect deep ocean chemistry on centennial timescales as per Gehlen et al. (2008). In addition, the small but increasing changes in total ocean alkalinity during the 1700-yr timespan of our simulations suggest the beginning of the carbonate compensation process (e.g. Archer and Maier-Reimer, 1994). This process would contribute significantly to the neutralization of anthropogenic $\mathrm{CO}_{2}$ on longer timescales than simulated here.

\subsection{Caveats}

A number of caveats must be taken into account in this study. First, we note that the inclusion of the ballast effect of $\mathrm{CaCO}_{3}$ on settling organic matter fluxes (e.g. Armstrong et al., 2002) would likely decrease the sensitivity of $\mathrm{CaCO}_{3}$ burial to the $\mathrm{CaCO}_{3}$ export flux by reducing the variability in sediment rain ratios. As such, the ballast effect might partially, if not entirely, counteract the negative $\mathrm{CO}_{2}$-calcification feedback as in Barker et al. (2003). Secondly, making $\mathrm{CaCO}_{3}$ dissolution in the water column dependent on $\Omega_{\mathrm{CaCO}_{3}}$ would further alter the vertical ocean alkalinity and DIC gradients through a reduction in the PIC:POC rain ratio and, consequently, increase the strength of the $\mathrm{CO}_{2}$ calcification feedback presented here. Such an exacerbation of the vertical alkalinity and gradients would be even more pronounced with the inclusion of aragonite due to its greater solubility relative to calcite. Finally, it is possible that the lack of representation of iron limitation on marine primary production in the UVic ESCM is in part compensated by the strong temperature dependency of phytoplankton growth. Adding iron to the existing nitrate and phosphate tracers in the model might reduce the enhancement of primary production, and hence calcification, with increasing temperature thereby increasing the strength of the $\mathrm{CO}_{2}$ calcification feedback.

\section{Conclusions}

This study has shown that the response of the marine $\mathrm{CaCO}_{3}$ cycle to anthropogenic $\mathrm{CO}_{2}$ may hinge on the degree by which increased temperatures accelerate plankton growth, compared to the degree by which acidification hinders calcification. Greater sensitivity to acidification shifts carbon partitioning between atmosphere, ocean, and marine sediments by weakening the vertical ocean alkalinity and DIC gradients and decreasing sediment burial of $\mathrm{CaCO}_{3}$. Both of these effects increase surface ocean alkalinity. As 
a result, ocean carbon uptake is enhanced by producing an equivalent decrease in warming by year 3500. In the absence of a strong sensitivity of calcifiers to acidification, the climate feedback on the carbon cycle is positive, increasing the airborne fraction of carbon as the ocean warms (Schmittner et al., 2008). Our results suggest that the effect of the $\mathrm{CaCO}_{3}$ production- $\Omega_{\mathrm{CaCO}_{3}}$ relationship on the marine carbon cycle is significant for future climate projections on millennial timescales. This effect is in addition to the serious effects that acidification is expected to have on pelagic and coastal biota. Improving the representation of long-term carbon cycle processes in models will help us to quantify and evaluate the millennial-scale climate legacy that we may bequeath to future generations.

Acknowledgements. This study was funded by HDM's Nouveaux Chercheurs grant from the Fonds Québécois de la Recherche sur la Nature et la Technologie, the National Science and Engineering Research Council of Canada, the Canadian Foundation for Climate and Atmospheric Sciences, the Global Environmental and Climate Change Center, and Concordia University.

Edited by: L. Bopp

\section{References}

Andersson, A. J., Mackenzie, F. T., and Lerman, A.: Coastal ocean $\mathrm{CO}_{2}$-carbonic acid-carbonate sediment system of the Anthropocene, Global Biogeochem. Cy., 20, GB1S92, doi:10.1029/2005gb002506, 2006.

Archer, D.: Modeling the calcite lysocline, J. Geophys. Res.Oceans, 96, 17037-17050, doi:10.1029/91JC01812, 1991.

Archer, D.: A data-driven model of the global calcite lysocline, Global Biogeochem. Cy., 10, 511-526, 1996.

Archer, D.: Fate of fossil fuel $\mathrm{CO}_{2}$ in geologic time, J. Geophys. Res.-Oceans, 110, C09S05, doi:10.1029/2004jc002625, 2005.

Archer, D. and Maier-Reimer, E.: Effect of deep-sea sedimentary calcite preservation on atmospheric $\mathrm{CO}_{2}$ concentration, Nature, 367, 260-263, 1994.

Archer, D., Kheshgi, H., and Maier-Reimer, E.: Multiple timescales for neutralization of fossil fuel $\mathrm{CO}_{2}$, Geophys. Res. Lett., 24, 405-408, 1997.

Archer, D., Kheshgi, H., and Maier-Reimer, E.: Dynamics of fossil fuel $\mathrm{CO}_{2}$ neutralization by marine $\mathrm{CaCO}_{3}$, Global Biogeochem. Cy., 12, 259-276, doi:10.1029/98gb00744, 1998.

Armstrong, R. A., Lee, C., Hedges, J. I., Honjo, S., and Wakeham, S. G.: A new, mechanistic model for organic carbon fluxes in the ocean based on the quantitative association of POC with ballast minerals, Deep-Sea Res. Pt. II, 49, 219-236, 2002.

Barker, S., Higgins, J. A., and Elderfield, H.: The future of the carbon cycle: Review, calcification response, ballast and feedback on atmospheric $\mathrm{CO}_{2}$, Philos. T. Roy. Soc. A, 361, 1977-1998, doi:10.1098/rsta.2003.1238, 2003.

Bissinger, J. E., Montagnes, D. J. S., Sharples, J., and Atkinson, D.: Predicting marine phytoplankton maximum growth rates from temperature: Improving on the Eppley curve us- ing quantile regression, Limnol. Oceanogr., 53, 487-493, doi:10.4319/lo.2008.53.2.0487, 2008.

Brewer, P. G. and Goldman, J. C.: Alkalinity changes generated by phytoplankton growth, Limnol. Oceanogr., 21, 108-117, 1976.

Broecker, W. S. and Peng, T. H.: The role of $\mathrm{CaCO}_{3}$ compensation in the glacial to interglacial atmospheric $\mathrm{CO}_{2}$ change, Global Biogeochem. Cy., 1, 15-29, doi:10.1029/GB001i001p00015, 1987.

Caldeira, K. and Wickett, M. E.: Ocean model predictions of chemistry changes from carbon dioxide emissions to the atmosphere and ocean, J. Geophys. Res.-Oceans, 110, C09S04, doi:10.1029/2004JC002671, 2005.

Cao, L. and Caldeira, K.: Atmospheric $\mathrm{CO}_{2}$ stabilization and ocean acidification, Geophys. Res. Lett., 35, L19609, doi:10.1029/2008g1035072, 2008.

Cox, P. M.: Description of the "TRIFFID” dynamic global vegetation model, Hadley Center Technical Note 24, Met Office, Exeter, UK, 2001.

Delille, B., Harlay, J., Zondervan, I., Jacquet, S., Chou, L., Wollast, R., Bellerby, R. G. J., Frankignoulle, M., Borges, A. V., Riebesell, U., and Gattuso, J. P.: Response of primary production and calcification to changes of $p \mathrm{CO}_{2}$ during experimental blooms of the coccolithophorid Emiliania huxleyi, Global Biogeochem. Cy., 19, GB2023, doi:10.1029/2004gb002318, 2005.

Denman, K. L., Brasseur, G., Chidthaisong, A., Ciais, P., Cox, P. M., Dickinson, R. E., Hauglustaine, D., Heinze, C., Holland, E., Jacob, D., Lohmann, U., Ramachandran, S., Da Silva Dias, P. L., Wofsy, S. C., and Zhang, X.: Couplings between changes in the climate system and biogeochemistry, in: Climate Change 2007: The Physical Science Basis. Contribution of Working Group I to the Fourth Assessment Report of the Intergovernmental Panel on Climate Change, edited by: Solomon, S., Qin, D., Manning, M., Chen, Z., Marquis, M., Averyt, K. B., Tignor, M., and Miller, H. L., Cambridge University Press, Cambridge, UK and New York, NY, USA, 2007.

Doney, S. C.: The consequences of human-driven ocean acidification for marine life, Biology Reports Ltd., 1, available at: http: //f1000.com/reports/b/1/36/ (last access: 28 June 2012), 2009.

Doney, S. C.: The growing human footprint on coastal and open-ocean biogeochemistry, Science, 328, 1512-1516, doi:10.1126/science.1185198, 2010.

Doney, S. C., Fabry, V. J., Feely, R. A., and Kleypas, J. A.: Ocean acidification: The other $\mathrm{CO}_{2}$ problem, Annu. Rev. Marine Sci., 1, 169-192, doi:10.1146/annurev.marine.010908.163834, 2009.

Eby, M., Zickfeld, K., Montenegro, A., Archer, D., Meissner, K. J., and Weaver, A. J.: Lifetime of anthropogenic climate change: Millennial time scales of potential $\mathrm{CO}_{2}$ and surface temperature perturbations, J. Climate, 22, 2501-2511, doi:10.1175/2008jcli2554.1, 2009.

Emerson, S. and Bender, M.: Carbon fluxes at the sediment-water interface of the deep-sea: Calcium carbonate preservation, J. Mar. Res., 39, 139-162, 1981.

Engel, A., Zondervan, I., Aerts, K., Beaufort, L., Benthien, A., Chou, L., Delille, B., Gattuso, J., Harlay, J., Heemann, C., Hoffmann, L., Jacquet, S., Nejstgaard, J., Pizay, M., Rochelle-Newall, E., Schneider, U., Terbrueggen, A., and Riebesell, U.: Testing the direct effect of $\mathrm{CO}_{2}$ concentration on a bloom of the coccolithophorid Emiliania huxleyi in mesocosm experiments, Limnol. Oceanogr., 50, 493-507, 2005. 
Eppley, R. W.: Temperature and phytoplankton growth in the sea, Fish. B.-NOAA, 70, 1063-1085, 1972.

Fabry, V. J.: Shell growth rates of pteropod and heteropod mollusks and aragonite production in the open ocean: Implications for the marine carbonate system, J. Mar. Res., 48, 209-222, doi:10.1357/002224090784984614, 1990.

Feely, R. A., Sabine, C. L., Lee, K., Berelson, W., Kleypas, J., Fabry, V. J., and Millero, F. J.: Impact of anthropogenic $\mathrm{CO}_{2}$ on the $\mathrm{CaCO}_{3}$ system in the oceans, Science, 305, 362-366, 2004.

Francois, R., Honjo, S., Krishfield, R., and Manganini, S.: Factors controlling the flux of organic carbon to the bathypelagic zone of the ocean, Global Biogeochem. Cy., 16, 1087, doi:10.1029/2001gb001722, 2002.

Gangst $\varnothing$, R., Gehlen, M., Schneider, B., Bopp, L., Aumont, O., and Joos, F.: Modeling the marine aragonite cycle: changes under rising carbon dioxide and its role in shallow water $\mathrm{CaCO}_{3}$ dissolution, Biogeosciences, 5, 1057-1072, doi:10.5194/bg-5-10572008, 2008.

Gangst $\varnothing$, R., Joos, F., and Gehlen, M.: Sensitivity of pelagic calcification to ocean acidification, Biogeosciences, 8, 433-458, doi:10.5194/bg-8-433-2011, 2011.

Gehlen, M., Gangst $\varnothing$, R., Schneider, B., Bopp, L., Aumont, O., and Ethe, C.: The fate of pelagic $\mathrm{CaCO}_{3}$ production in a high $\mathrm{CO}_{2}$ ocean: a model study, Biogeosciences, 4, 505-519, doi:10.5194/bg-4-505-2007, 2007.

Gehlen, M., Bopp, L., and Aumont, O.: Short-term dissolution response of pelagic carbonate sediments to the invasion of anthropogenic $\mathrm{CO}_{2}$ : A model study, Geochem. Geophy. Geosy., 9, Q02012, doi:10.1029/2007gc001756, 2008.

Gent, P. R. and McWilliams, J. C.: Isopycnal mixing in ocean circulation models, J. Phys. Oceanogr., 20, 150-155, 1990.

Heinze, C.: Simulating oceanic $\mathrm{CaCO}_{3}$ export production in the greenhouse, Geophys. Res. Lett., 31, L16308, doi:10.1029/2004g1020613, 2004.

Hinga, K. R.: Effects of $\mathrm{pH}$ on coastal marine phytoplankton, Mar. Ecol.-Prog. Ser., 238, 281-300, doi:10.3354/meps238281, 2002.

Hofmann, M. and Schellnhuber, H. J.: Oceanic acidification affects marine carbon pump and triggers extended marine oxygen holes, P. Natl. Acad. Sci. USA, 106, 3017-3022, doi:10.1073/pnas.0813384106, 2009.

Iglesias-Rodriguez, M. D., Halloran, P. R., Rickaby, R. E. M., Hall, I. R., Colmenero-Hidalgo, E., Gittins, J. R., Green, D. R. H., Tyrrell, T., Gibbs, S. J., Von Dassow, P., Rehm, E., Armbrust, E. V., and Boessenkool, K. P.: Phytoplankton calcification in a high- $\mathrm{CO}_{2}$ world, Science, 320, 336-340, doi:10.1126/science.1154122, 2008.

Ilyina, T., Zeebe, R. E., Maier-Reimer, E., and Heinze, C.: Early detection of ocean acidification effects on marine calcification, Global Biogeochem. Cy., 23, GB1008, doi:10.1029/2008gb003278, 2009.

Jin, X., Gruber, N., Dunne, J. P., Sarmiento, J. L., and Armstrong, R. A.: Diagnosing the contribution of phytoplankton functional groups to the production and export of particulate organic carbon, $\mathrm{CaCO}_{3}$, and opal from global nutrient and alkalinity distributions, Global Biogeochem. Cy., 20, doi:10.1029/2005gb002532, 2006.

Key, R. M., Kozyr, A., Sabine, C. L., Lee, K., Wanninkhof, R., Bullister, J. L., Feely, R. A., Millero, F. J., Mordy, C., and Peng, T. H.: A global ocean carbon climatology: Results from Global
Data Analysis Project (GLODAP), Global Biogeochem. Cy., 18, GB4031, doi:10.1029/2004gb002247, 2004.

Kirchman, D. L. and Rich, J. H.: Regulation of bacterial growth rates by dissolved organic carbon and temperature in the equatorial Pacific Ocean, Microb. Ecol., 33, 11-20, doi:10.1007/s002489900003, 1997.

Klaas, C. and Archer, D. E.: Association of sinking organic matter with various types of mineral ballast in the deep sea: Implications for the rain ratio, Global Biogeochem. Cy., 16, 1116, doi:10.1029/2001gb001765, 2002.

Langer, G., Geisen, M., Baumann, K. H., Klas, J., Riebesell, U., Thoms, S., and Young, J. R.: Species-specific responses of calcifying algae to changing seawater carbonate chemistry, Geochem. Geophy. Geosy., 7, Q09006, doi:10.1029/2005gc001227, 2006.

Lee, K.: Global net community production estimated from the annual cycle of surface water total dissolved inorganic carbon, Limnol. Oceanogr., 46, 1287-1297, 2001.

Lenton, T. M. and Britton, C.: Enhanced carbonate and silicate weathering accelerates recovery from fossil fuel $\mathrm{CO}_{2}$ perturbations, Global Biogeochem. Cy., 20, GB3009, doi:10.1029/2005gb002678, 2006.

Meissner, K. J., Weaver, A. J., Matthews, H. D., and Cox, P. M.: The role of land surface dynamics in glacial inception: A study with the UVic Earth System Model, Clim. Dynam., 21, 515-537, doi:10.1007/s00382-003-0352-2, 2003.

Millero, F. J.: The thermodynamics of the carbonate system in seawater, Geochim. Cosmochim. Ac., 43, 1651-1661, doi:10.1016/0016-7037(79)90184-4, 1979.

Orr, J. C., Fabry, V. J., Aumont, O., Bopp, L., Doney, S. C., Feely, R. A., Gnanadesikan, A., Gruber, N., Ishida, A., Joos, F., Key, R. M., Lindsay, K., Maier-Reimer, E., Matear, R., Monfray, P., Mouchet, A., Najjar, R. G., Plattner, G., Rodgers, K. B., Sabine, C. L., Sarmiento, J. L., Schlitzer, R., Slater, R. D., Totterdell, I. J., Weirig, M., Yamanaka, Y., and Yool, Y.: Anthropogenic ocean acidification over the twenty-first century and its impact on calcifying organisms, Nature, 437, 681-686, doi:10.1038/nature04095, 2005.

Passow, U. and De la Rocha, C. L.: Accumulation of mineral ballast on organic aggregates, Global Biogeochem. Cy., 20, GB1013, doi:10.1029/2005gb002579, 2006.

Pomeroy, L. R. and Wiebe, W. J.: Temperature and substrates as interactive limiting factors for marine heterotrophic bacteria, Aquat. Microb. Ecol., 23, 187-204, doi:10.3354/ame023187, 2001.

Raven, J. A. and Falkowski, P. G.: Oceanic sinks for atmospheric $\mathrm{CO}_{2}$, Plant Cell Environ., 22, 741-755, 1999.

Ridgwell, A. J.: An end to the "rain ratio" reign?, Geochem. Geophy. Geosy., 4, 1051, doi:10.1029/2003gc000512, 2003.

Ridgwell, A. and Hargreaves, J. C.: Regulation of atmospheric $\mathrm{CO}_{2}$ by deep-sea sediments in an Earth system model, Global Biogeochem. Cy., 21, GB2008, doi:10.1029/2006gb002764, 2007.

Ridgwell, A., Hargreaves, J. C., Edwards, N. R., Annan, J. D., Lenton, T. M., Marsh, R., Yool, A., and Watson, A.: Marine geochemical data assimilation in an efficient Earth System Model of global biogeochemical cycling, Biogeosciences, 4, 87-104, doi:10.5194/bg-4-87-2007, 2007a.

Ridgwell, A., Zondervan, I., Hargreaves, J. C., Bijma, J., and Lenton, T. M.: Assessing the potential long-term increase of oceanic fossil fuel $\mathrm{CO}_{2}$ uptake due to $\mathrm{CO}_{2}$-calcification feed- 
back, Biogeosciences, 4, 481-492, doi:10.5194/bg-4-481-2007, 2007b.

Ridgwell, A., Schmidt, D. N., Turley, C., Brownlee, C., Maldonado, M. T., Tortell, P., and Young, J. R.: From laboratory manipulations to Earth system models: scaling calcification impacts of ocean acidification, Biogeosciences, 6, 2611-2623, doi:10.5194/bg-6-2611-2009, 2009.

Riebesell, U., Zondervan, I., Rost, B., Tortell, P. D., Zeebe, R. E., and Morel, F. M. M.: Reduced calcification of marine plankton in response to increased atmospheric $\mathrm{CO}_{2}$, Nature, 407, 364-367, 2000.

Sabine, C. L., Feely, R. A., Gruber, N., Key, R. M., Lee, K., Bullister, J. L., Wanninkhof, R., Wong, C. S., Wallace, D. W. R., Tilbrook, B., Millero, F. J., Peng, T., Kozyr, A., Ono, T., and Rios, A.: The oceanic sink for anthropogenic $\mathrm{CO}_{2}$, Science, 305 , 367-371, doi:10.1126/science.1097403, 2004.

Sarmento, H., Montoya, J. M., Vazquez-Dominguez, E., Vaque, D., and Gasol, J. M.: Warming effects on marine microbial food web processes: How far can we go when it comes to predictions?, Philos. T. Roy. Soc. B, 365, 2137-2149, doi:10.1098/rstb.2010.0045, 2010.

Sarmiento, J. L., Dunne, J., Gnanadesikan, A., Key, R. M., Matsumoto, K., and Slater, R.: A new estimate of the $\mathrm{CaCO}_{3}$ to organic carbon export ratio, Global Biogeochem. Cy., 16, 1107, doi:10.1029/2002gb001919, 2002.

Schartau, M. and Oschlies, A.: Simultaneous data-based optimization of a 1D-ecosystem model at three locations in the North Atlantic: Part I - Method and parameter estimates, J. Mar. Res., 61, 765-793, doi:10.1357/002224003322981147, 2003.

Schmittner, A., Oschlies, A., Giraud, X., Eby, M., and Simmons, H. L.: A global model of the marine ecosystem for long-term simulations: Sensitivity to ocean mixing, buoyancy forcing, particle sinking, and dissolved organic matter cycling, Global Biogeochem. Cy., 19, GB3004, doi:10.1029/2004gb002283, 2005a.

Schmittner, A., Oschlies, A., Giraud, X., Eby, M., and Simmons, H. L.: Decline of the marine ecosystem caused by a reduction in the Atlantic overturning circulation, Nature, 434, 628-633, doi:10.1038/nature03476, 2005b.

Schmittner, A., Oschlies, A., Matthews, H. D., and Galbraith, E. D.: Future changes in climate, ocean circulation, ecosystems, and biogeochemical cycling simulated for a business-as-usual $\mathrm{CO}_{2}$ emission scenario until year $4000 \mathrm{AD}$, Global Biogeochem. Cy., 22, GB1013, doi:10.1029/2007gb002953, 2008.

Sciandra, A., Harlay, J., Lefèvre, D., Lemée, R., Rimmelin, P., Denis, M., and Gattuso, J. P.: Response of coccolithophorid Emiliania huxleyi to elevated partial pressure of $\mathrm{CO}_{2}$ under nitrogen limitation, Mar. Ecol.-Prog. Ser., 261, 111-122, doi:10.3354/meps261111, 2003.
Secretariat of the convention on biological diversity: Scientific Synthesis of the Impacts of Ocean Acidification on Marine Biodiversity, Technical Series No. 46, Montreal, 61 pp., 2009.

Simmons, H. L., Jayne, S. R., St. Laurent, L. C., and Weaver, A. J.: Tidally driven mixing in a numerical model of the ocean general circulation, Ocean Model., 6, 245-263, doi:10.1016/s14635003(03)00011-8, 2004.

Steinacher, M., Joos, F., Frölicher, T. L., Bopp, L., Cadule, P., Cocco, V., Doney, S. C., Gehlen, M., Lindsay, K., Moore, J. K., Schneider, B., and Segschneider, J.: Projected 21st century decrease in marine productivity: a multi-model analysis, Biogeosciences, 7, 979-1005, doi:10.5194/bg-7-979-2010, 2010.

Sundquist, E. T.: Geological perspectives on carbon dioxide and the carbon cycle, in: The Carbon Cycle and Atmospheric $\mathrm{CO}_{2}$ : Natural Variations, Archean to Present, American Geophysical Union Monograph 32, edited by: Broecker, W. S. and Sundquist, E. T., American Geophysical Union, Washington, DC, 5-59, 1985.

Sundquist, E. T.: Influence of deep-sea benthic processes on atmospheric $\mathrm{CO}_{2}$, Philos. T. Roy. Soc. A, 331, 155-165, doi:10.1098/rsta.1990.0062, 1990.

Weaver, A. J., Eby, M., Wiebe, E. C., Bitz, C. M., Duffy, P. B., Ewen, T. L., Fanning, A. F., Holland, M. M., Macfadyen, A., Matthews, H. D., Meissner, K. J., Saenko, O., Schmittner, A., Wang, H., and Yoshimori, M.: The UVic Earth System Climate Model: Model description, climatology, and applications to past, present and future climates, Atmos. Ocean., 39, 361-428, 2001.

White, P. A., Kalff, J., Rasmussen, J. B., and Gasol, J. M.: The effect of temperature and algal biomass on bacterial production and specific growth-rate in fresh-water and marine habitats, Microb. Ecol., 21, 99-118, doi:10.1007/bf02539147, 1991.

Zeebe, R. E., Zachos, J. C., Caldeira, K., and Tyrrell, T.: Oceans - Carbon emissions and acidification, Science, 321, 51-52, doi:10.1126/science.1159124, 2008.

Zondervan, I., Zeebe, R. E., Rost, B., and Riebesell, U.: Decreasing marine biogenic calcification: A negative feedback on rising atmospheric $p \mathrm{CO}_{2}$, Global Biogeochem. Cy., 15, 507-516, 2001.

Zondervan, I., Rost, B., and Riebesell, U.: Effect of $\mathrm{CO}_{2}$ concentration on the PIC/POC ratio in the coccolithophore Emiliania huxleyi grown under light-limiting conditions and different daylengths, J. Exp. Mar. Biol. Ecol., 272, 55-70, doi:10.1016/s0022-0981(02)00037-0, 2002. 